\title{
Ice genesis and its long-term mass balance and dynamics in Scărişoara Ice Cave, Romania
}

\author{
A. Perşoiu ${ }^{1}$ and A. Pazdur ${ }^{2}$ \\ ${ }^{1}$ University of South Florida, Department of Geology, 4202 E Fowler Ave., SCA 528, Tampa, 33620, Fl, USA \\ ${ }^{2}$ Silesian University of Technology, Institute of Physics, Department of Radioisotopes (GADAM Centre of Excellence), \\ Krzywoustego 2, 44-100 Gliwice, Poland
}

Received: 9 September 2010 - Published in The Cryosphere Discuss.: 6 October 2010

Revised: 10 December 2010 - Accepted: 28 December 2010 - Published: 31 January 2011

\begin{abstract}
The paleoclimatic significance of the perennial ice deposit in Scărişoara Ice Cave has been remarked on since the early 20th century, but a lack of understanding of the processes involved in the genesis, age and long-term dynamics and volume fluctuations of ice hampered all attempts to extract valuable data on past climate and vegetation changes. In this paper, we present a model of ice genesis and dynamics, based on stable isotopes, ice level monitoring (modern and archived) and radiocarbon dating of organic matter found in the ice. Ice in this cave mostly consists of layers of lake ice, produced as liquid water freezes from top to bottom in mid-autumn, and floor ice, produced as inflow water in winter freezes on top of the lake ice. This mechanism was also acting in the past, during the Medieval Warm Period and the Little Ice Age. The ice block is not stable in shape and volume, being continuously modified by ablation on top and sides, basal melting and lateral flow. Radiocarbon dating shows that the ice block is older than 1000 years, but ice flow and differential basal melting suggesting that the ice could be much older.
\end{abstract}

\section{Introduction}

Ice caves are a common feature of mid-altitude mountains in Europe, where a combination of cave morphology and local climate makes the perennial accumulation of ice possible. They were a rather underestimated subject for scientific research, with only a few of them (e.g., Dobsinšká L'adová Jeskiňa, Kungur Ice Cave, Scărişoara Ice Cave) being investigated in more detail. Over the past decade, a series of studies have targeted ice caves as sources of paleoclimatic information (Citterio et al., 2004a; Fórizs et al., 2004, Kern et al., 2004, Holmlund et al., 2005; Luetscher, 2005; Luetscher et al., 2007; Kern et al., 2009) and hence resurrecting the interest in their study. Although promising, the paleoclimatic potential of the perennial ice in caves is hampered by the lack of understanding of the complex systematics of ice genesis, mass balance fluctuations and age (e.g., Luetscher et al., 2007), as well as the way in which the climatic signal is being transferred from the exterior to the ice (e.g., Perşoiu et al., 2007). Moreover, stratigraphic gaps detected in the ice could prove to be difficult to date and thus make the paleoclimatic reconstructions a challenging attempt.

In 2003, an ambitious paleoclimatic research program has been initiated in Scărişoara Ice Cave (Holmlund et al., 2005) with the intent to reconstruct the climatic and vegetation history of the area surrounding the cave by analyzing various proxies found in the ice (oxygen and hydrogen stable isotopes, pollen, macrofossils, etc). The aim of this paper is to review the processes related to the genesis of ice in Scărişoara Ice Cave, as well as to propose a mechanism for the initiation of ice accumulation and its long term volume variations and dynamics, as a starting point for further paleoclimatic studies. 

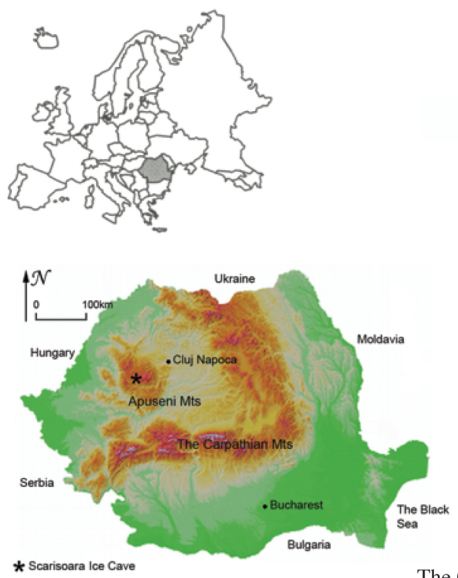

The Church (Biserica)

(B)

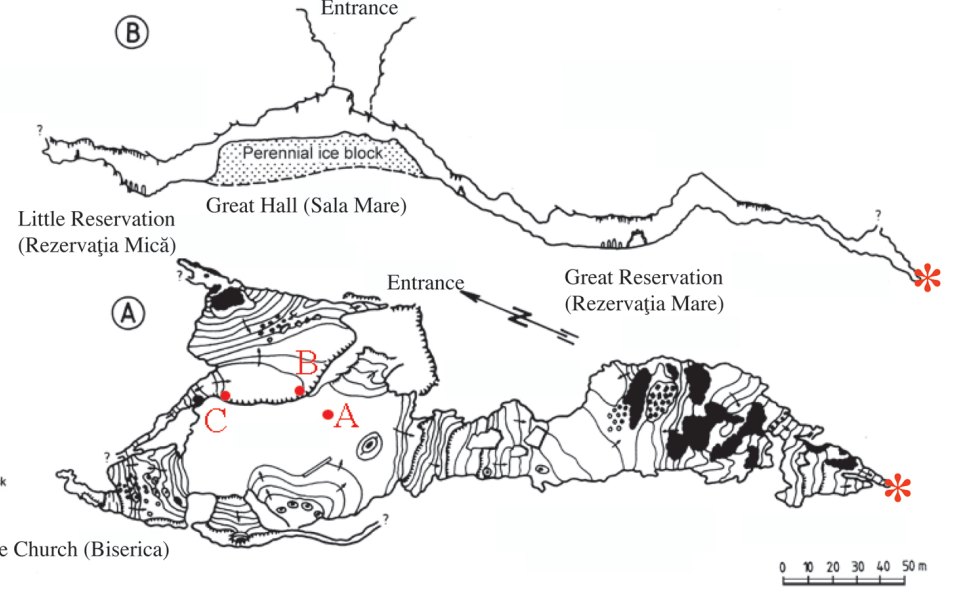

Fig. 1. Location map, plan view (A) and cross section (B) of Scărişoara Ice Cave (modified from Rusu et al., 1970). The red points mark: (A) position of the cores drilled in 2005 and 2009, (B) position of SCL1, SCL2 and SCL 3 samples for radiocarbon dating, (C) position of SCL4, SCL5, SCL6, SCL7 and SCL 8 samples for radiocarbon dating. The red star marks the position of the collapse passage that was linking Scărişoara Ice Cave and Pojarul Poliţei Cave (see main text for details).

\section{Site description}

Scărişoara Ice Cave (700 m long, $105 \mathrm{~m}$ deep) is located in the Apuseni Mountains (Fig. 1), a massive, steep-sided mountain range in Central Europe, at $1165 \mathrm{~m}$ a.s.l.

The cave is carved in thickly bedded Upper-Jurassic limestones (Bucur and Onac, 2000), its entrance being located on the western wall of a circular shaft $60 \mathrm{~m}$ in diameter and $47 \mathrm{~m}$ deep, the bottom of which is covered by a perennial layer of snow. Beyond the entrance, the ice block, with a volume of $\sim 100000 \mathrm{~m}^{3}$ and area extent of $3000 \mathrm{~m}^{2}$, forms the floor of the Great Hall, its vertical sides delimiting three distinct sectors of the cave: The Church ("Biserica"), Little Reservation ("Rezervaţia Mică") and Great Reservation ("Rezervaţia Mare") (Fig. 1).

Towards the NW, the horizontal floor ends with a steep slope dipping $8 \mathrm{~m}$ toward the small Church Hall, with an ice covered floor and over 100 perennial ice stalagmites. The Little Reservation is on the northern side of the Great Hall and can be entered by descending an $\sim 18$-m high vertical cliff, along which the ice stratification is visible. In the central part of the room, not far from the ice block, a field of ice stalagmites forms. The entrance to the Great Reservation is located on the southern side of the Great Hall. Within this part of the cave, the largest rooms are found ( 20 to $45 \mathrm{~m}$ wide and up to $20 \mathrm{~m}$ high). Here the ice forms a steep slope to a depth of $90 \mathrm{~m}$ below the surface and $43 \mathrm{~m}$ below the level of the Great Hall. On the horizontal bedrock floor in the central part of the Great Reservation is another field of ice stalagmites similar to the ones in the Little Reservation. In both Great and Little Reservations, a variety of calcite speleothemes have developed in the inner non-glaciated parts of the cave.
The climate of the region is continental temperate, showing a strong influence of the westerlies. The mean annual temperature near the cave is $\sim 5.2^{\circ} \mathrm{C}$; the temperatures $(T)$ of the coldest month (January), and warmest (July) are around $-4^{\circ} \mathrm{C}$, and $15^{\circ} \mathrm{C}$, respectively.

The prevailingly western circulation of the air in the Apuseni Mountains causes large precipitation amounts (over $1600 \mathrm{~mm}$ per year at Stâna de Vale, some $30 \mathrm{~km}$ to the NW) to fall on their western slopes, whereas on the eastern slopes the annual amounts are reduced by half (below $850 \mathrm{~mm}$ at Băişoara, ca. $35 \mathrm{~km}$ to the NE). In the area surrounding the cave, the mean annual precipitation varies around $1200 \mathrm{~mm}$, with the highest values in spring and early summer months and the lowest values in October.

The mean duration of the interval when the snow layer is likely to exist is estimated to be $150-180$ days per year. Maximum values of the snow pack depth can exceed $1 \mathrm{~m}$ at the bottom of dolines, and 3-4 $\mathrm{m}$ at the bottom of the Scărişora Ice Cave's entrance shaft.

The climate of Scărişoara Ice Cave is a direct consequence of the external climatic variations and underground ventilation caused by the presence of a single entrance and mainly descendent passages (Onac et al., 2007). This peculiar morphology leads to cold air inflow inside the cave during winter months, triggered by the higher density of the cold external air masses compared to the warmer ones inside, while in summer, the same density difference prevents the exchange of air masses between the two environments.

Within the cave, Racoviţă (1984) distinguished four climatic zones: a transitional zone in the entrance shaft, a glacial zone comprising the area occupied by the ice block (Great Hall, The Church), a periglacial zone (Little and Great Reservation), and a warm climate zone in the non-glaciated 
parts of the cave (Coman Passage and Sânziana's Palace). The spatial repartition of these climatic zones is reflected in the thermal pattern of the cave: while in Great Hall the mean annual temperature is around $-0.9{ }^{\circ} \mathrm{C}$, it increases to $-0.2^{\circ} \mathrm{C}$ in the Great Reservation and $4.2^{\circ} \mathrm{C}$ in the Coman Passage.

The air temperature has the greatest variations in the glacial meroclimate. During the periods with cold air inflow in winter (extending from late October to early April), the temperature closely follows the external climate evolution and may decrease below $-15^{\circ} \mathrm{C}$. During summer, when aerodynamic exchanges with the surface cease, the underground temperature is independent from external variations, being influenced only by the thermal inertia of the ice block and the overcooled walls of the cave, rarely increasing above $+0.5^{\circ} \mathrm{C}$ (Racoviţă, 1994a).

Air circulation is one of the most important factors affecting the mass balance of the ice in the cave. We can distinguish between two seasonal types of circulation: one occurring in summer and the other in winter. Between November and April, airflow triggered by the higher density of external cold air is directed from the surface downward into the cave. The inflowing cold $\left(T_{\min }<-15^{\circ} \mathrm{C}\right)$ and dry (relative humidity $<75 \%$ ) air first reaches the Great Hall, where it descends along the flanks of the ice block into the Little and Great Reservations, displacing the warmer air, which is pushed out along the ceilings. Between May and October, no air mass exchange occurs between the cave and the outside, as the cold air in the cave is denser than the external air. Meanwhile, the overcooled walls of the cave and ice block account for the persistence of cold air masses in the Great Hall, while the inner parts of the two Reservations warm slowly under the influence of geothermal heat and the heat capacity of the rock. Thus, this difference in air temperature triggers a slow air movement between the Great Hall and the two Reservations, the airflow following almost the same path as in winter. The difference is that the rising warm air is progressively cooled as it reaches the walls of the Great Hall and sinks to the bottom of it, closing the convective cell. In April and October, rapid changes between summer and winter types of circulation occur as temperature varies around $0^{\circ} \mathrm{C}$.

\section{Methods}

In order to meet the above objectives, the following set of analyses was performed. Firstly, observations and measurements of ice dynamics and level changes were carried out between August 2004 and June 2005 and between August 2008 and January 2009. Additionally, two shallow ice cores were drilled in January 2005 and 2009, containing ice formed in the previous months only. The cores were cut respectively into six (core B, 2005) and five (core A, 2009) equal pieces, allowed to melt at room temperature, and then $\delta^{18} \mathrm{O}$ and $\delta^{2} \mathrm{H}$ were measured on the resulting water (see Perşoiu et al.,
2011, for details of the analytical techniques). Ice samples from an ice core extracted in the Great Hall in 2003 (Holmlund et al., 2005) were also recovered for stable isotope analysis. Each of these samples consists of a layer of ice and cryogenic calcite (Žák et al., 2008) at its base, and thus are taught to have formed in one year. The results of the stable isotope analyses are reported in \%o versus SMOW, the analytical precision $(2 \sigma)$ being better than $0.2 \%$ and $1.0 \%$ for oxygen and hydrogen, respectively.

Eight samples of organic matter (Picea abies branches) were collected in August 2006 from the $\sim 18$-m high exposed wall in the Little Reservation, and radiocarbon analyzes were performed in the Gliwice Radiocarbon Laboratory, using the Liquid Scintillation Counting method on a Quantullus 1220 spectrometer (Pazdur et al., 2003). Calibration of the raw data was performed using the OxCal 4.1 software and the INTCAL09 dataset of Reimer et al. (2009).

For the short-term level fluctuations assessment, the following measurements from the Great Hall were used: (1) our own measurements performed between October 2000 and July 2010; (2) the monthly (between April 1982 and December 1992) measurements of Racoviţă (1994b), and (3) older ice level data collected since December 1947 and reported by Racoviţă and Onac (2000) and Racoviţă (1994b). The distance between the ice surface and the overhanging rock wall was measured, the data thus reflecting the summed mass loss and gain at both the upper and lower parts of the block. In order to distinguish between the two, a secondary data set was obtained, by measuring the ice level changes against the 1982 level on a $50 \mathrm{~cm}$-long line, which was inserted into the ice in April 1982. By subtracting the two data sets, it was also possible to calculate a second order parameter, i.e., the rate of melting at the sole of the ice block (Perşoiu, 2005). Ice flow was assessed by monitoring the movement of a marker inserted in the upper face of the ice block against the rock wall in the Great Hall.

\section{Results and discussions}

The results of ice level measurements, presented in Fig. 2, show a strong ice loss between 1947 and 1980, followed by a period of relative stability with ice build-up in the mid80s and in 2006 and 2010. Melting at the base of the ice block was determined for the 1982-1992 observational period, being relatively constant, at a rate of about $1.5 \mathrm{~cm} /$ year (Perşoiu, 2005).

The results of the radiocarbon dating are shown in Table 1. The upper $9 \mathrm{~m}$ of the ice block, as well as the lowermost one (ca. $10 \mathrm{~m}$ below the lowermost dated horizon) was not dated, due to lack of organic matter in the ice. Three samples were collected in the eastern side of the ice wall, and the remaining five in the central and western part of it (Fig. 3). All radiocarbon ages are in correct stratigraphic order, except for samples SCL 4 and SCL 8. Sample SCL 8 was collected 
Table 1. Results of the radiocarbon analysis of samples collected from Scărişoara Ice Cave.

\begin{tabular}{|c|c|c|c|c|c|}
\hline Sample name & Lab. No. & $\begin{array}{l}\text { Depth below } \\
\text { surface }(\mathrm{cm})\end{array}$ & Age ${ }^{14} \mathrm{C}$ & $\begin{array}{l}\text { Calibrated age range (AD) } \\
\text { at both } 1 \sigma \text { and } 2 \sigma\end{array}$ & Date used \\
\hline \multicolumn{6}{|l|}{ Western side } \\
\hline SCL 8 & Gd-12924 & 901 & $495 \pm 45$ & $\begin{array}{l}\text { AD } 1405-1450(68.2 \%) 1 \sigma \\
\text { AD } 1388-1471(84.0 \%) 2 \sigma \\
\text { AD } 1316-1355(11.4 \%) 2 \sigma\end{array}$ & Not used \\
\hline SCL 7 & Gd-15990 & 1005.5 & $265 \pm 65$ & $\begin{array}{l}\text { AD } 1512-1601(32.6 \%) 1 \sigma \\
\text { AD } 1453-1692(72.2 \%) 2 \sigma \\
\text { AD } 1728-1811(17.45) 2 \sigma\end{array}$ & AD 1600 \\
\hline SCL 6 & Gd-12922 & 1125.5 & $330 \pm 50$ & $\begin{array}{l}\text { AD } 1494-1532(20.2 \%) 1 \sigma \\
\text { AD } 1537-1602(36.35) 1 \sigma \\
\text { AD } 1454-1649(95.4 \%) 2 \sigma\end{array}$ & AD 1565 \\
\hline SCL 5 & Gd-15988 & 1571 & $820 \pm 70$ & $\begin{array}{l}\text { AD } 1156-1276(68.2 \%) 1 \sigma \\
\text { AD } 1040-1285(95.4 \%) 2 \sigma\end{array}$ & AD 1216 \\
\hline SCL 4 & Gd-16416 & 1682.4 & $810 \pm 130$ & $\begin{array}{l}\text { AD } 1147-1288(48.6 \%) 1 \sigma \\
\text { AD } 1045-1097(13.9 \%) 1 \sigma \\
\text { AD } 985-1407(95.4 \%) 2 \sigma\end{array}$ & AD 1196 \\
\hline \multicolumn{6}{|l|}{ Eastern side } \\
\hline SCL 3 & Gd-12918 & 1262.4 & $800 \pm 50$ & $\begin{array}{l}\text { AD } 1207-1275(64.2 \%) 1 \sigma \\
\text { AD } 1153-1287(93.0 \%) 2 \sigma\end{array}$ & Not used \\
\hline SCL 1 & GdS-458 & 1345.4 & $890 \pm 45$ & $\begin{array}{l}\text { AD } 1048-1087(22.7 \%) 1 \sigma \\
\text { AD } 1150-1212(37.1 \%) 1 \sigma \\
\text { AD } 1027-1225(95.4 \%) 2 \sigma\end{array}$ & Not used \\
\hline SCL 2 & GdS-459 & 1467.4 & $1000 \pm 50$ & $\begin{array}{l}\text { AD } 986-1048(43.6 \%) 1 \sigma \\
\text { AD } 1087-1123(18.8 \%) 1 \sigma \\
\text { AD } 1138-1150(5.8 \%) 1 \sigma \\
\text { AD } 952-1162(92.4 \%) 2 \sigma\end{array}$ & Not used \\
\hline
\end{tabular}

from a disturbed section of the wall, where the ice folds due to differential flow velocities which cause overturning of the ice layers (see below) and was excluded from the depth-age model. Samples SCL1, SCL 2 and SCL3 were also excluded from the depth-age model as they are very closely spaced in time and partially overlap, and also because the thickness of ice layers is not similar in the eastern and western sides of the block and hence an exact stratigraphic correlation between the two sequences could not be made. The radiocarbon age-depth model is based on linear interpolation between the midpoints (minim of $60 \%$ at $1 \sigma$ or $2 \sigma$ calibrated ranges; Fig. 4).

The stable isotope values of ice of the short ice cores drilled in the upper face of the ice block, as well as those from the deeper part of the ice block, are shown Fig. 5. A clear trend of isotopic depletion with depth is displayed for both cores, due to isotopic fractionation processes in the forming ice (Jouzel and Souchez, 1984; Perşoiu et al., 2011).

\subsection{The mechanism of ice formation}

Most of the previous work in Scărişoara Ice Cave (Racoviţă, 1927; Şerban et al., 1948; Racoviţă and Onac, 2000), as well as other places (Luetscher, 2004) explained the formation of ice as a polygenetic processes, where both freezing of ice and diagenesis of snow interplay to form a new layer of ice each year. The snow that accumulates at the bottom of the entrance shaft to Scărişoara Ice Cave is only 1-3 m thick, not enough to allow compaction under its own weight to form ice. Moreover, the reduced thickness of the snow pack allows percolating water (from melting snow and summer rains) to reach the bottom of it quickly, without freezing to further form ice. The freezing of water inside the snow pack is also prevented by the relatively high (between 0 and $0.5^{\circ} \mathrm{C}$ ) air and snow temperatures (Racoviţă, 1994a). Most of the snow at the bottom of the shaft melts and drains away through fissures in the underlying limestone, with only occasional inflow towards the ice block. 


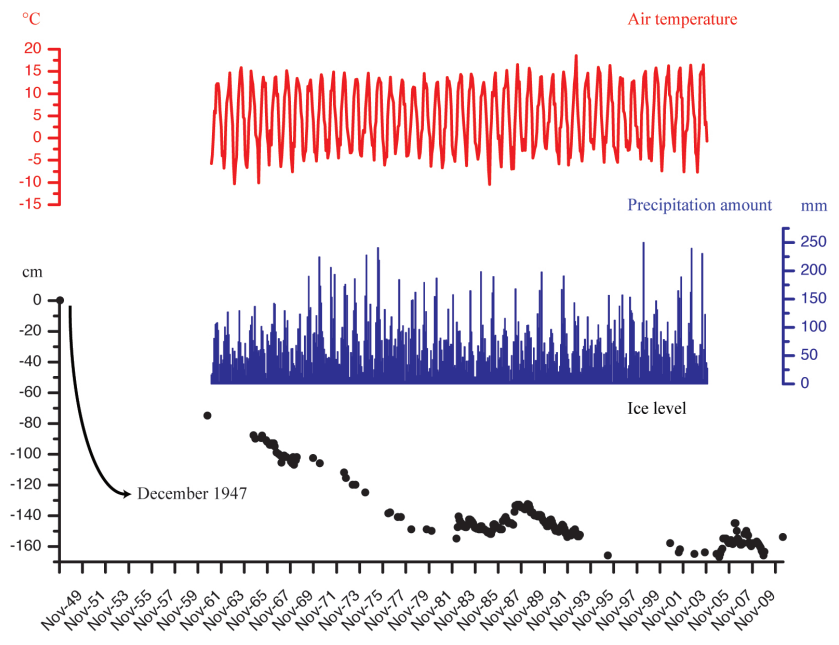

Fig. 2. Short-term ice level fluctuations in Scărişoara Ice Cave (1947-2010, modified from Racoviţă, 1994b) against the air temperature and precipitation amount recorded at Băişoara Meteorological Station (1961-2003).

Observations over the past 10 years have shown that the ice block is built up by in situ freezing of water. This is a multi-stage processes, with two types of ice (Perşoiu et al., 2011) being formed during the accumulation season, lasting between mid-September (earliest) and early-June (latest). In mid-autumn, under the influence of cold air sinking inside the cave, a shallow lake that accumulates during the melting season starts to freeze from top to bottom, to form layer of ice approximately $10-15 \mathrm{~cm}$ thick. On top of this layer of so-called "lake ice", thinner layers of ice (termed "floor ice") could form during the winter, when occasional warmer and wetter weather leads to water infiltration inside the cave (through the highly fractured and bedded rock ceiling directly above the ice block) and its subsequent freezing in the colder environment. Thus, at the end of the accumulation period, the newly formed layer of ice is composed of two entities: lake ice at the bottom, formed in mid-autumn, and floor ice on top, formed in warmer winter periods. Beginning with mid-April, melting begins, driven by the infiltration of warm precipitation waters (Perşoiu, 2004) that lead to a rapid ablation of the upper face of the block. By mid-summer, most of the floor ice is melted and the resulting water drained away through a narrow channel carved in the ice. Reduction of precipitation amount in the summer months (Orăşeanu and Varga, 2003) stops the melting, and the drainage channel quickly fills up with ice: thus, proper conditions develop for the accumulation of a new lake, which will freeze in the next autumn.

This model of ice genesis is further supported by stable isotope data (Fig. 5). The two ice cores were extracted at the end of the lake ice formation phase, and the $\delta^{18} \mathrm{O}$ and $\delta^{2} \mathrm{H}$ data show an evident decreasing trend from top to bottom. This trend could only be explained by the formation of ice through a downward freezing process in which the heavy isotopes of $\mathrm{O}$ and $\mathrm{H}$ are preferentially incorporated in the ice, leaving the remaining water strongly depleted (Jouzel and Souchez, 1982; Souchez and Jouzel, 1984; and firstly described for cave ice by Citterio et al., 2004b). A similar trend of ${ }^{18} \mathrm{O}$ - and ${ }^{2} \mathrm{H}$-depletion has been found in ice layers that were dated to 740 and 289 cal BP (Perşoiu et al., 2010), hence showing that ice formed in a similar way both during the Medieval Warm Period (MWP) and the subsequent Little Ice Age (LIA). Moreover, stable isotope analysis (Žák et al., 2008) of cryogenic cave calcite (CCC) found at the bottom of the cores revealed extremely high values of $\delta^{13} \mathrm{C}$ (up to $+12 \%$ PDB), typical for calcite formed during fast freezing of water (Žák et al., 2004, 2008). Degassing of $\mathrm{CO}_{2}$ during freezing is also responsible for the formation of bubbles within the lake ice, as they are trapped under the first layer of ice to form on top of the lake's water; as opposite to floor ice, where degassing $\mathrm{CO}_{2}$ freely escapes to the cave's atmosphere. Similar values (up to $+9 \%$ PDB) were found in CCC from ice layers formed during the MWP and LIA, further supporting the genesis of ice by the freezing of water also under different climatic conditions. However, both during the LIA and MWP ice must have formed also as floor ice (not only lake ice), and melting must have led to loss of both ice types, so it would be difficult to assess the contribution of the two types of ice to the built-up of the ice block.

\subsection{Ice mass balance fluctuations and dynamics}

On an annual cycle the level fluctuations of the upper face of the ice block show a cyclic behavior, with a maximum in late spring and a minimum in late summer (Racoviţă et al., 1987; Racoviţă, 1994b). Longer-term fluctuations are superimposed on this annual cycle under the influence of external temperature and precipitation amount, with the warmer but drier summers (e.g., 2006 and 2010) and warmer but wetter winters (e.g., 2005-2006 and 2009-2010) leading to less melting and more ice accumulation (Fig. 2). The wet summers of 2005 and 2009 led to a rapid ablation of the ice, while the colder and drier winters between 2001 and 2003 did not allow for much floor ice build-up. This pattern follows that of the past ca. 60 years (Fig. 2), with periods of ice build-up corresponding to drier summers and generally colder years, and periods of ablation associated with wetter and/or warmer years (Racoviţă, 1994b).

The accumulation of the perennial ice block in Scărişoara Ice Cave must have started after the collapse of the passage in the Great Reservation (see Fig. 1) that was linking the cave with Pojarul Politei Cave, passage that was allowing free circulation of air through the cave and thus preventing its cooling. Seasonal ice could have been formed before this collapse, but it was possibly melting away in the summer season under the influence of air circulation, as seen in nearby caves with two entrances situated at different altitudes (as Scărişoara Ice Cave must have been at that time). Ice could 

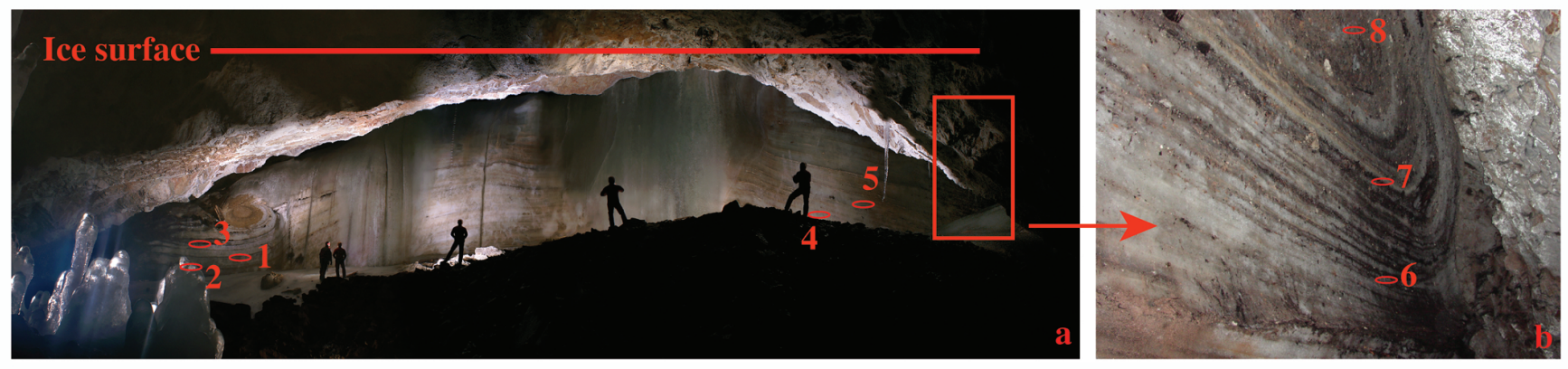

Fig. 3. The exposed wall of the ice block as seen from the Little Reservation, with the position of radiocarbon ages shown.

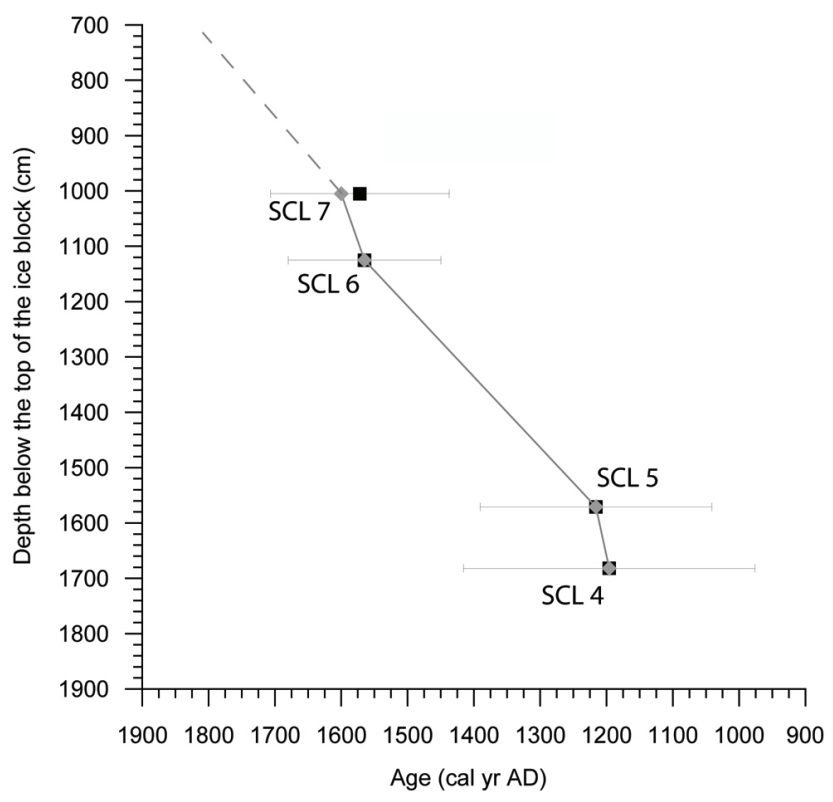

Fig. 4. Depth-age model of the exposed ice wall in Little Reservation, Scărişoara Ice Cave.

have started to accumulate during the last glacial, as Onac and Lauritzen (1996) have shown that dripping water was available inside the cave some $55 \mathrm{kyrs}$ ago (based on U/Th dating of stalagmites from the cave), but the survival of such old ice is improbable, as basal melting is high enough (see above) and the ice must have melted away.

We consider that the inception and accumulation of ice in the cave must have followed the scheme in Fig. 6, with considerable fluctuations between the main stages, under both external (climatic) and internal (ice flow) controllers.

The first (semi) perennial ice that accumulated inside the cave (Fig. 6a) changed the cave's own climate, its melting over the summer consuming all the heat delivered to the cave by conduction (through the air column in the entrance shaft and the rock walls) and dripping water, as well as by the geothermal heat, thus maintaining the temperatures at $0{ }^{\circ} \mathrm{C}$. Two possible sites are good candidates for the inception of

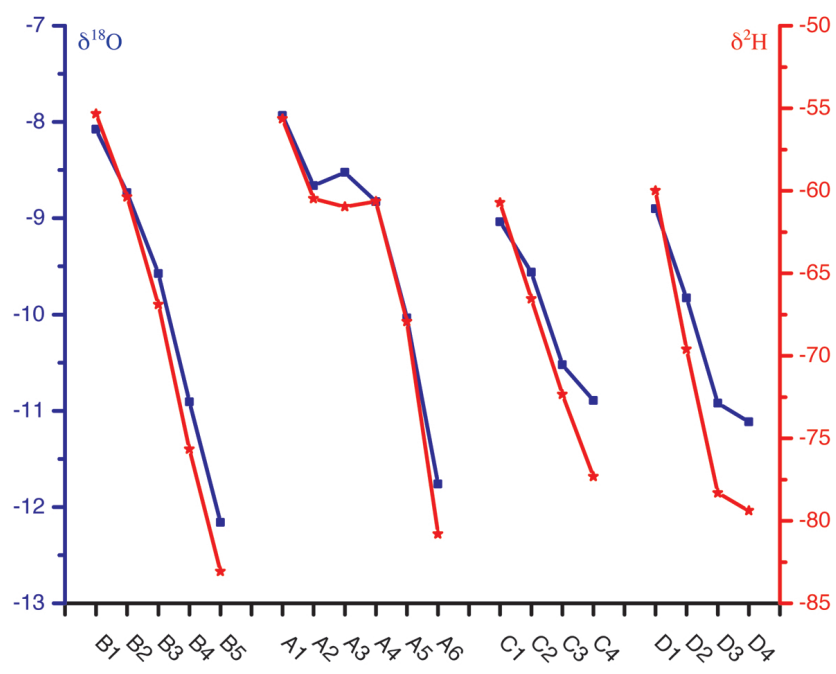

Fig. 5. $\delta^{18} \mathrm{O}$ (blue line and left axis) and $\delta^{2} \mathrm{H}$ (red line and right axis) profiles in the ice cores (A drilled in 2009, B drilled in 2005, $\mathrm{C}$ is ice from the LIA and D is ice from the MWP) drilled on top of the ice block in Scărişoara Ice Cave.

the ice: the upper part of the debris cone underneath the entrance shaft and in the Great Hall and the two lowermost sections of the cave (Fig. 6a). We do not think that a lake could have developed on top of the debris cone in the Great Hall, but, nevertheless, ice was developing as dripping water was freezing to form ice speleothemes and a thin layer of floor ice (an ubiquitous process observed in the cave over the past 60 years). In the deeper parts of the cave a similar processes must have acted (as it does today); and, additionally, water could have pooled on the rock floor and freeze to further form ice. A positive feed-back loop was established inside the cave, and ice started to grow rapidly, the ever increasing (in steps) ice volume (Fig. 6b) helping to keep the temperature at $0{ }^{\circ} \mathrm{C}$ for longer time. Şerban et al. (1948) suggested that ice at one time filled the cave completely, leaving the innermost sections of it out of the reach of inflowing cold air. These authors have proposed that melting started in the isolated parts of the cave, leading to the retreat of the ice from 

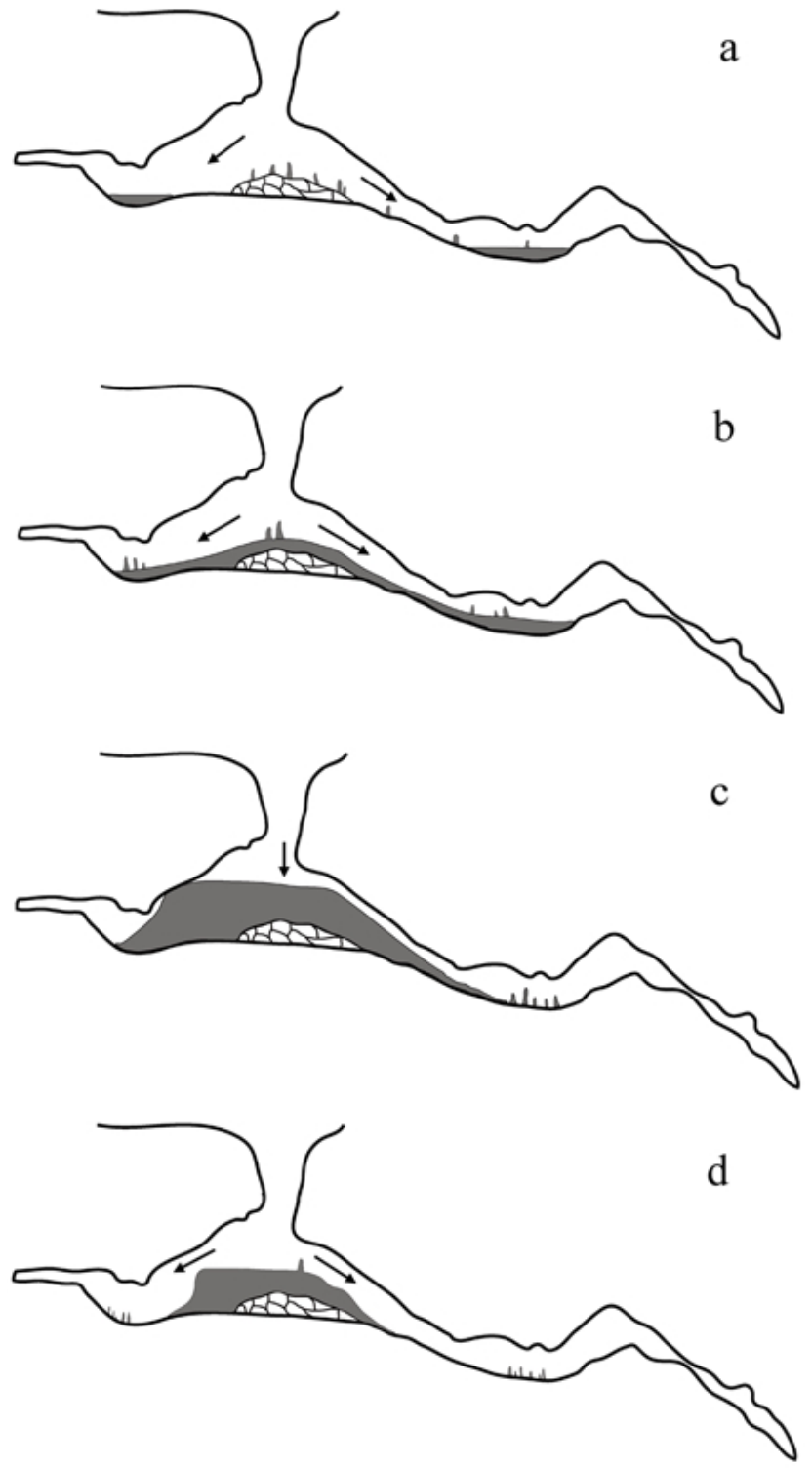

Fig. 6. A conceptual model of the genesis and long-term volume fluctuations of the ice block in Scărişoara Ice Cave (see main text for details). Arrows indicate the direction of cold air inflow.

the walls and the subsequent formation of the ice cliffs towards the Little and Great Reservation (Fig. 6c). Thus, the ice block must have evolved into the shape of a pyramid, with a flat surface (formed by the freezing of lake water) and vertical (or inclined) lateral walls (formed by the retreat due to melting). Visitors to the cave in the 19th century (Schmidl, 1863) noticed the horizontal surface and the opening towards the Great Reservation only; that towards the Little Reservation being sealed off by ice coming in contact with the rock wall. Following the warming after the end of the LIA (Popa and Kern, 2009), the ice started to recede (both from below and from top downwards, Fig. 6c) so that by 1947, the opening towards the Little Reservation was visible (Şerban et al.,
1948). An exceptionally fast melting occurred between 1947 and 1963 (Fig. 2), when the upper face of the block lowered by ca. $75 \mathrm{~cm}$, possibly due to the opening of the entrance towards the Little Reservation (Fig. 6d), which led to rapid loss of water that otherwise would have frozen and built up as ice.

The accumulation of ice was not continuous, nor was the ice block stable. The layering of the ice block (Fig. 3) is an indicator of the lateral flow of the ice towards the walls. The fold visible in Fig. $3 \mathrm{~b}$ must have formed as ice was flowing to fill in the empty space remaining as it was retreating from the walls. Observations over the past 60 years have shown that melting starts at the triple junction between the rock wall, rock floor and ice wall (Fig. 6c), where the amount of heat delivered to the ice block is maximized, so that the an opening is created at the base of the ice wall while its upper part is still in contact with the rock wall. Monitoring over the past 10 years has shown that the ice is flowing with a velocity of about $3 \mathrm{~cm} /$ year from east to west, towards the direction of the fold. Two conspicuous layers of organic matter are visible at the two ends of the exposed wall, the middle of it being covered by ice formed after the opening of the entrance at the upper face of the ice block (Fig. 6d). Both layers were formed in the middle to late MWP. Şerban et al. (1948) and Pop and Ciobanu (1950) have suggested that these layers have formed as enhanced melting led to the merging of a series of annual layers. Alternatively, these layers could have also formed as result of strong in wash of material from the outside following heavy individual rains. The accumulation rate during the MWP, calculated based on the SCL1, SCL2 and SCL 3 radiocarbon ages was between 0.9 and $1.6 \mathrm{~cm} / \mathrm{yr}$, similar to the modern rate $(1.3 \mathrm{~cm} / \mathrm{yr}$, based on data from 1982 to 2010). Following the end of the MWP and during the LIA, the accumulation rate remained unchanged, as the possible lower accumulation during the colder winters (less water available) was being compensated by less melting in the colder summers. This constancy of the accumulation rate during different climatic conditions is due to the complex interplay between the climatic factors that control the level (and mass balance) fluctuations of ice, i.e., wet vs. dry summers and/or winters and cold vs. warm summers and/or winters. As seen above, a cold but dry winter will lead to less ice accumulation as a warmer, but wetter one, while a warm but dry summer will lead to less melting than a cold, but wet one. As a consequence, the possibility of extracting a good climatic signal from the various proxies in the ice (stable isotopes, pollen) is very promising, provided that more dating is performed.

Melting at the base and sides of the ice block led to lateral flow of the ice in the middle and lower sections of the block, while the presence of the rock wall prevented flow in the upper part, hence leading to the development of a fold. Based on radiocarbon dating on this section, ice thickness measurements and geothermal flux values (normal for the area, as suggested by Demetrescu and Andreescu, 1994), Holmlund et al. (2005) give an age of about 2000 years for the onset 
of the folding. The presence of the fold, as well as present day measurements of ice level fluctuations (see above), show that basal melting does occur at the base of the ice block. However, the inclined layers of ice visible on the side of the ice block, as well as the stratigraphy of an ice core extracted from the middle of it (Holmlund et al., 2005), suggests that this melting is not uniform, and that it is acting only at the sides of the ice block, where geothermal heat is delivered to both sole and the sides of the block. Moreover, ice temperature measurements at the base of the bore hole drilled in 2003, both at the time of drilling and the years after, show that temperature was constantly below $-2{ }^{\circ} \mathrm{C}$, hence preventing melting at this point. Consequently, we suggest that basal melting occurs only near the sides of the ice block, thus leading to a slow lateral flow and subsequent thinning of the layers in the middle area. It could possibly be that ice at the base of the block in its middle part could be much older than on its side, reaching back in time towards the mid to early Holocene.

\section{Conclusions}

Ice-forming processes, long-term dynamics and mass balance changes of ice in Scărişoara Ice Cave have been investigated. Results from this investigation show that the ice in the cave forms by the freezing of water in a two-stage process, one in mid-autumn (lake ice is formed) and one lasting from early winter to late spring (floor ice is formed); while summer melting leads to ice loss, mostly of the floor ice. The ice block was formed by the successive growth of lake and floor ice layers, these processes acting in a similar way during (at least) the past 1000 years; but their relative contribution to the build up of the ice block being unknown. The ice block is at least 1000 years old (the deepest part of it was not yet dated), but Pop and Ciobanu (1950) suggest an age of ca. 3000 years for the base of it, based on pollen assemblage data. The relatively similar accumulation rates during the MWP and LIA are a consequence of the complex interplay between ice gain and loss, with periods of low (high) accumulation being compensated by periods of similarly low (high) ablation. Periods of exceptional melt might have led to the destruction of the annual layering of the ice block (as it happened in the 20th century), thus making the extraction and interpretation of any paleoclimatic information problematic. A combination of careful visual detection of hiatuses and radiocarbon dating above and below them (possible due to the high content in organic matter within the ice, see Fig. 3) might solve this problem. Stable isotopes in ice were shown to be a promising candidate for past air temperature reconstructions (Perşoiu et al., 2011), and thus good promises exist that ice in caves (at least in this particular case) could be used to reconstruct past climatic changes.
Acknowledgements. This study is based on work supported by a Cave Conservancy Foundation fellowship to AP and a NSF grant AGS-0823253 to B. P. Onac. We thank Angelica Feurdean for help with discussion on the radiocarbon ages and construction of the depth-age model, and Beth Fratesi and Angelica Feurdean for language corrections. Comments and suggestion by Valter Maggi, Charles Yonge and Michele Citterio greatly improved the quality and clarity of the manuscript. The photo for Fig. 3a was provided by Gigi Frăţilă and Claudiu Szabo.

Edited by: F. Obleitner

\section{References}

Bucur, I. I. and Onac, B. P.: New data concerning the age of Mesozoic limestone from Scărişoara (Bihor Mountains), Studia UBB Geologia, XLV (2), 13-20, 2000.

Citterio, M., Turri, S., Bini, A., Maggi, V., Pelfini, M., Pini, R., Ravazzi, C., Santilli, M., Stenni, B., and Udisti, R.: Multidisciplinary approach to the study of the Lo Lc 1650 "Abisso sul Margine dell'Alto Bregai” ice cave (Lecco, Italy), Theor. Appl. Karstol., 17, 45-50, 2004a.

Citterio, M., Turri, S., Bini, A. and Maggi, V.: Observed trends in the chemical composition, $\delta^{18} \mathrm{O}$ and crystal sizes vs. depth in the first ice core from the LoLc 1650 "Abisso sul Margine dell' Alto Bregai” ice cave (Lecco, Italy), Theor. Appl. Karstol., 17, 27-44, 2004b.

Demetrescu, C. and Andreescu, M.: On the thermal regime of some tectonic units in a continental collision environment in Romania, Tectonophysics, 230(3-4), 265-276, 1994.

Holmlund, P., Onac, B. P., Hansson, M., Holmgren, K., Morth, M., Nyman, N., and Perşoiu, A.: Assessing the palaeoclimate potential of cave glaciers: the example of the Scărişoara Ice Cave (Romania), Geogr. Ann. A., 87, 193-201, 2005.

Johnston, V. E., McDermott, F., and Tămaş, T.: A radiocarbon dated bat guano deposit from N.W. Romania: Implications for the timing of the Little Ice Age and Medieval Climate Anomaly, Palaeogeogr. Palaeocl., 291, 217-227, 2010.

Jouzel, J. and Souchez, R. A.: Melting refreezing at the glacier sole and the isotopic composition of the ice, J. Glaciol., 28, 35-42, 1982.

Kern, Z., Fórizs, I., Nagy, B., Kázmér, M., Gál, A., Szánto, Z., Palcsu, L., and Molnár, M.: Late Holocene environmental changes recorded at Gheţarul de la Focul Viu, Bihor Mountains, Romania, Theor. Appl. Karstol., 17, 51-60, 2004.

Kern, Z., Molnár, M., Svingor, E., Perşoiu, A., and Nagy, B.: Highresolution, well-preserved tritium record in the ice of Borţig Ice Cave, Bihor Mountains, Romania, The Holocene, 19(5), 729736, 2009.

Fórizs, I., Kern, Z., Szántó, Z., Nagy, B., Palcsu, L., and Molnár, M.: Environmental isotopes study on perennial ice in the Focul Viu Ice Cave, Bihor Mountains, Romania, Theor. Appl. Karstol., 17, 61-69, 2004.

Luetscher, M.: Processes in ice caves and their significance for paleoenvironmental reconstruction, Ph.D. thesis, Swiss Institute for Speleology and karts Studies, Switzerland, 2005.

Luetscher, M. and Jeannin, P.-Y.: A process-based classification of alpine ice caves, Theor. Appl. Karstol., 17, 5-10, 2004. 
Luetscher, M., Bolius, D., Schwikowski, M., Schotterer, U., and Smart, P. L.: Comparison of techniques for dating of subsurface ice from Monlesi ice cave, Switzerland, J. Glaciol., 53, 374-384, 2007.

Onac, B. P. and Lauritzen, S. E.: The climate of the last 150,000 years recorded in speleothemes: preliminary results from northwestern Romania. Theor. Appl. Karstol. 9, 9-21, 1996.

Onac, B. P., Perşoiu, A., Racoviţă, G., Tămaş, T., and Viehmann, I.: Scărişoara Ice Cave and its surroundings, Studia, Cluj Napoca, Romania, 88 pp., 2007.

Orăşeanu I. and Varga, I.: Meteorological data in the Gheţar area (com. Gârda de Sus, jud. Alba) (1 ${ }^{\text {st }}$ part), Nymphaea, XXX, 324, 2003 (in Romanian).

Pazdur, A., Fogtman, M., Michczynski, A., and Pawlyta, J.: Precision of ${ }^{14} \mathrm{C}$ dating in Gliwice Radiocarbon Laboratory, FIRI Programme, Geochronometria, 22, 27-40, 2003.

Perşoiu, A.: Ice speleothemes in Scărişoara Ice Cave: dynamics and controllers, Theor. Appl. Karstol., 17, 71-76, 2004.

Perşoiu, A.: Evidence of basal melting of the ice block from Scărişoara Ice Cave, in: Glacier Caves and Glacial Karst in High Mountains and Polar Regions, edited by: Mavlyudov, B. R., Moscow, 109-112, 2005.

Perşoiu, A., Bojar, A.-V., and Onac, B. P.: Stable isotopes in cave ice: what do they tell us?, Studia UBB Geologia, 52(1), 59-62, 2007.

Perşoiu, A., Onac, B. P. and Feurdean A.: Multi-proxy climatic and environmental record for the last 1000 years in the western Carpathians, Romania, in: Abstract volume, 4th International Workshop on Ice Caves, edited by: Spötl, C., Luetscher, M., and Ritter, P., Obertraun, 29, 2010.

Perşoiu, A., Onac, B. P., Wynn, J., Bojar, A.-V., and Holmgren, K.: Stable isotopes behavior during cave ice formation by water freezing in Scărişoara Ice Cave, Romania, J. Geophys. Res., 116, D02111, doi:10.1029/2010JD014477, 2011.

Pop, E. and Ciobanu, I.: Analize de polen în ghiaţa de la Scărişoara, Anal. Acad. Rom, GGB, III (2), 23-52, 1950.

Popa, I. and Kern, Z.: Long-term summer temperature reconstruction inferred from tree-ring records from the Eastern Carpathians, Clim. Dynam., 32, 1107-1117, 2009.

Racoviţă, E.: Observations sur la glaciere naturelle dite "Gheţarul de la Scărişoara”, Bull. Soc. Sci. Cluj, III, 75-108, 1927.

Racoviţă, G.: Sur la structure méroclimatique des cavités souterraines, Theor. Appl. Karstol., 1, 123-130, 1984.
Racoviţă, G.: Bilan climatique de la grotte glaciere de Scărişoara, dresse sur dix annees d'observations, Trav. de L'Institute de Spéologie "Emil Racovitza" XXXIII, 107-158, 1994a.

Racoviţă, G.: Elements fondamentaux dans la dynamique des spéléothèmes de glace de la grotte de Scărişoara, en relation avec la météorologie externe, Theor. Appl. Karstol. 7, 133-148, 1994b.

Racoviţă, G., Şerban, M., and Viehmann, I.: Tendances de long terme dans la dynamique des formations de glace de la Grotte de Scărişoara (Monts du Bihor), Theor. Appl. Karstol., 3, 143-164, 1987.

Racoviţă, G. and Onac, B. P.: Scărişoara glacier cave, Monographic study, Editura Carpatica, Cluj-Napoca, Romania, 2000.

Reimer, P. J., Baillie, M. G. L., Bard, E., Bayliss, A., Beck, J. W., Blackwell, P. G., Bronk Ramsey, C., Buck, C. E., Burr, G. S., Edwards, R. L., Friedrich, M., Grootes, P. M., Guilderson, T. P., Hajdas, I., Heaton, T. J., Hogg, A. G., Hughen, K. A., Kaiser, K. F., Kromer, B., McCormac, F. G., Manning, S. W., Reimer, R. W., Richards, D. A., Southon, J. R., Talamo, S., Turney, C. S. M., van der Plicht, J., and Weyhenmeyer, C. E.: IntCal09 and Marine09 radiocarbon age calibration curves, $0-50,000$ years cal BP., Radiocarbon 51, 1111-1150, 2009.

Rusu, T., Racoviţă, G. and Coman, D.: Contributions a l'etude du complex carstique de Scărişoara, Ann. Speleol, 25, 383-408, 1970.

Schmidl, A.: Das Bihar-Gebirge an der Grenze von Ungarn und Siebenbürgen, Verlag Förster und Bartelemeus, Wien, 442 pp., 1963.

Souchez, R. A. and Jouzel, J.: On the isotopic composition in $\delta \mathrm{D}$ and $\delta^{18} \mathrm{O}$ of water and ice during freezing, J. Glaciol. 30, 369372, 1984.

Şerban, M., Coman, D. and Givulesco, R.: Decouvertes récentes et observations sur la glacière naturelle dite "Gheţarul de la Scărişoara", Bulletin de la société des sciences de Cluj, Roumanie, X, 174-210, 1948.

Žák, K., Urban, J., Cílek, V., and Hercman, H.: Cryogenic cave calcite from several Central European caves: age, carbon and oxygen isotopes and a genetic model, Chem. Geol., 206, 119136, 2004.

Žák, K., Onac, B. P., and Perşoiu, A.: Cryogenic carbonates in cave environments: A review. Quat. Int., 187, 84-96, 2008. 